\title{
Determinants of Accounting Students' Competency: Kuwait University
}

\author{
Sadik Albassam ${ }^{1}$, Abdullah Alawadi ${ }^{1} \&$ Wael Alrashed ${ }^{1}$ \\ ${ }^{1}$ Accounting Department, College of Business Administration, Kuwait University, Kuwait \\ Correspondence: Wael Alrashed, Accounting Department, College of Business Administration, Kuwait University, \\ Kuwait.
}

Received: May 15, 2019

Accepted: June 4, 2019

Online Published: June 16, 2019

doi:10.5430/ijba.v10n4p30

URL: https://doi.org/10.5430/ijba.v10n4p30

\begin{abstract}
Kuwait University is the only state university with accounting education that has commenced in 1966. So far, accounting education is offered by the College of Business Administration - CBA- as a full degree of 4 years span, in addition to some other private universities that started recently. CBA periodically reviews the accounting program particularly after earning AACSB accreditation in the late 90's, which has pressed for more academic excellence. CBA has introduced an exit exam process in 2009 since inception. Results revealed some areas of concern such as the shallow technical background of graduates, ill-use of advanced accounting systems and software, and inadequate research ability. One would add to these, student's tendency toward the classical type of learning or "spoon feeding", which questions their ability in the judgmental type of cases as well as their self-expression.

The purpose of this research is to explore factors associated with accounting student's competencies at Kuwait University and subsequently to suggest remedy policies. A survey has been conducted through out the period from April 2018 till August 2018 exploring factors affecting accounting student's competency. Multiple factors that influence student's competencies were entrenched within a statistical model which later resulted in comparable results. Moreover, stepwise multiple regression analysis was used to analyse the relationships between students' competency and the independent variables. Results expose that students lean heavily on in- class materials and do less reading in advance. Also, learning techniques used and practices by students are well classical as it depends primarily on lecturer delivering the materials. Finally, this study provides evidence that GPA earned by accounting students at CBA is the most important variable associated with their overall performance upon graduation. Other variables such as MGPA, external assistance (EA), in-class assignments (ICA), students' personal and technical abilities (PFT), and other financial and social factors (FT) have lesser degree of significance on their performance.
\end{abstract}

Keywords: accounting education, student compenecies, student performance, performance measures, competency determinants

\section{Introduction}

\subsection{Study's Objectives \& Importance}

The objective of this study is to explore accounting student's competencies and pinpointing factors affecting their competencies which in turn enhance their future career opportunities. At present, assessing how active CBA accounting student's competencies in meeting market needs is measured from the pure academic perspective and primarily depends on their grade point average (GPA) as well as the student's major GPA (MGPA), disregarding other parameters such as the personality, skills, and attitudes. Leadership, for example, is quite an essential factor that undoubtedly influences the performance of accounting students and must be included as an independent factor in measuring students' competency. It is intercorrelated with many other personal parameters that are out of the scope of this study and relates less to direct accounting competency in broad terms.

Identifying competency factors is also of paramount importance in reforming learning objectives, activities, as well as teaching techniques in the accounting department. Results would underline various parameters that are forming student performance such as the GPA, aptitude test, and other measurable personal attributes. In addition to the query to all registered students registering in the summer semester of the academic year 2017-2018, the exit exam is employed to determine these parameters and their related weight in shaping students' performance. It also assists in achieving optimal utilisation of resources as the country faces an extensive and very aggressive development plan, that would certainly require all professional workforce available. This would entail the adoption of a certain policy 
by both public and private universities, accounting departments, and the accounting profession at large to contribute to this national plan. Staff, students, and accreditation committees can also benefit from the study's findings in their manner.

\subsection{Kuwait Accounting Education}

Higher education in Kuwait has started around 55 years back. University education resembled by the only state university in the country has commenced in 1966. More regulation has been enforced when private universities decree was passed allowing for private universities to operate in Kuwait in 2002. Quality, as well as tight control on providing higher education, has always been the goal for the council for private universities- the body responsible for private university licenses and quality control.

As far as accounting education, Kuwait is considered a leading Arab country offering university level accounting program that has been overseen by the college of business administration-CBA- as a full-time degree of 4 years span. The accounting program is periodically reviewed by CBA as part of the accreditation maintenance process that started in 1996 and continued to ascertain quality assurance and regard for excellence in learning objectives. In this respect, CBA has introduced an exit exam as part of the accreditation maintenance process in 2009. Results revealed areas of concern that must be resolved if CBA is to maintain its international accreditation by AACSB. Neither Kuwait university bylaws nor higher education regulation in Kuwait has any reference to qualifying such exam among university graduates.

The accounting department is the largest among CBA's six departments with almost one-third of all CBA's students. The department Intakes are mostly female students earning highest score points on the aptitude tests as well as high school GPA. English proficiency is mandatory before being officially admitted to CBA. Otherwise, students must take some preparatory English courses before completing the 120 credit units required to earn their bachelor's degree in accounting. Some courses are core and form the skeleton of accounting knowledge, while others are electives in the business arena or general education.

\subsection{Accounting Workforce in Kuwait}

The Accounting department's mission is to supply the local market with well-educated and highly skilled accountants especially for those targeting distinct jobs within the private sector and the auditing profession in the country. On many occasions, officials in both the public and private sectors have appealed the improvement in accounting graduate's competencies to meet Kuwait's emerging market demands. On the other hand, some other locally published surveys on the adequacy of Kuwaiti graduates to labour market questioned the adequacy and quality of accounting education. Among their observations, they detected poor business knowledge of CBA graduates because students tend to do less reading in general business and financial issues primarily related to Kuwait and regional economies. This remark is to some extent true as CBA faculty members occasionally raise the dilemma on how to encourage students to be well prepared beforehand even though syllabus contains detailed timetable of weekly subjects and reminders are sent to them in advance. Few students who sat for exit exam in 2009 had a good knowledge base in general business, and some cases of those had stated in the exam sheet that they came across these materials for the first time.

Recommended solutions include revising curriculums, enforcing instructional tools, adopting unified syllabus and exam, requiring more English prerequisites, introducing IT in accounting $3^{\text {rd }}$ level courses, and imposing more than one advanced course within the $2^{\text {nd }}$ to the $4^{\text {th }}$ year curriculum. Additionally, $2^{\text {nd }}$-year students are to take basic IT applications in accounting, international financial reporting standards (IFRS) in some details, and professional skills comprehensively. $3^{\text {rd }}$ year accounting would contain more advanced issues in accounting information systems such as adopting collaboration software and automation in accounting. While $4^{\text {th }}$-year courses would contain projects on IT-based accounting such as billing systems, payroll, and auditing systems. An advanced version of these courses is taught at the master program as core courses or as term projects. CBA faculty are closely working with the IT department to strengthen accounting students' exposure to IT applications.

Moreover, the pressure is mounting on accounting faculty to produce entirely preset course materials, resulting in locally branded accounting tools and subsequent cases. CBA has celebrated its first publication of local cases handbook, which contained over 123 companies of different sectors with supporting data warehouses. For accounting policymakers in the country, all efforts are made to strengthen public awareness of IT accounting education in the country, which would undoubtedly improve students' competencies. Contracted research for concerned agencies such as the stock exchange and capital market authority would also expedite fulfilling the mission. 
Enhancing accounting students' competency is earning momentum as the whole region is getting into globalisation and international financial reporting. This entails considering all variables in restructuring the accounting department's strategic plan.

\subsection{Accounting Students' Performance}

Studies attempted to identify factors associated with accounting students' performance at CBA are quite rare. Alrashed (2001) in an early study found that most of these studies define performance as simply either the GPA or a grading score for a given accounting course. Using CBA's graduation database, the study examined the records of 183 accounting students which were on the graduation list of the academic year 2009-2010. Accounting graduates in the academic year 2010-2011 represent 31.6\% of total CBA students and 5.9\% of those graduating from all KU colleges.

Iinitial results (Table 1) revealed that the student's competencies are incredibly shocking. On the outset, reduced ability to communicate is widely observed among respondent even though they have spent the last three years in campus studying almost in same sections. On the accounting awareness aspect, norms among students are very generic even when it comes to defining basic concepts related to accounting era and the auditing profession. For example, when asked to reply to a very fundamental question "What do you know about accounting?" responses were amazingly fragile; poor (32\%), fair (28\%), and average (39\%). Accounting students seem to perform well in basic quantitative courses while they tend to slowly improve their competencies at little distinction as they proceed to more advanced management accounting courses. This is undoubtedly noticed in financial accounting and corporate accounting courses where grades are proportionally on the high side, whereas in managerial, auditing, accounting information systems, and accounting theory the performance is notably weak. Likewise, lack of consistency concerning accounting major and sub-content is common among respondents. Most students have completed their required major sheet courses with similarity in course requirements and grading system.

Few have come across self-learning experience within CBA classes or any other KU college, even though most students favour self-learning approaches when it comes to extra-curriculum content. Very seldom they score high in makeups or extra-assignments as compensation for poor exam(s) grades which led them to be disappointed with their grades. Some have indicated that the root of the problem goes beyond the capabilities of the university as it is related to high school's outputs, while other have put all the blame on KU and CBA courses primarily at the entry level. All in all, a preliminary reading of student's feedback, surely impose an issue to be pondered by KU officials.

Table 1 . Summary of preliminary data of students' responses (2009/2010)

\begin{tabular}{|c|c|c|c|c|}
\hline \multicolumn{3}{|c|}{ Students' Responses } & Measurement Objective & \multirow{2}{*}{$\begin{array}{l}\text { Queries } \\
1\end{array}$} \\
\hline Poor-- $32 \%$ & $\begin{array}{l}\text { Fair-- } \\
28.8 \%\end{array}$ & Average $39 \%$ & $\begin{array}{ll}\text { Basic } & \text { Accounting } \\
\text { Knowledge } & \end{array}$ & \\
\hline Financial & $36 \%$ & Sufficient & \multirow{7}{*}{$\begin{array}{l}\text { Students Awareness of } \\
\text { Accounting Diversity }\end{array}$} & \multirow{7}{*}{2} \\
\hline Auditing & $22 \%$ & Moderate & & \\
\hline Managerial & $16 \%$ & Poor & & \\
\hline AIS & $9 \%$ & Weak & & \\
\hline Finance & $7 \%$ & Weak & & \\
\hline $\begin{array}{l}\text { Management } \\
\& \text { Marketing }\end{array}$ & $6.7 \%$ & Weak & & \\
\hline $\begin{array}{l}\text { Acc. Ethics } \\
\text { Tax, Theory }\end{array}$ & $5.4 \%$ & Weak & & \\
\hline Text Readings & & Yes $7 \%$ - No 93\% & \multirow{4}{*}{$\begin{array}{l}\text { Extra-Curriculum } \\
\text { Activities }\end{array}$} & \multirow{4}{*}{3} \\
\hline \multicolumn{2}{|c|}{$\begin{array}{l}\text { Syllabus Content weekly } \\
\text { follow-up }\end{array}$} & Yes $4.7 \%$ - No $88 \%$ No reply $7.2 \%$ & & \\
\hline \multicolumn{2}{|c|}{ Student Motivation } & $\begin{array}{ll}\text { - } & \text { Web-Based coursing } \\
\text { - } & \text { RAT (reading ability tests) } \\
\text { - } & \text { Round quizzes } \\
\text { - } & \text { Compulsory Projects/interims }\end{array}$ & & \\
\hline \multicolumn{2}{|c|}{ Grading System } & - $5 \%$ Orals & & \\
\hline
\end{tabular}




\begin{tabular}{|c|c|c|c|c|}
\hline & $\begin{array}{ll}- & 75 \% \text { on Write-ups } \\
\text { - } & 20 \% \text { Group Work }\end{array}$ & & & \\
\hline Self Learning $68 \%$ & Content-Based 29.2\% & & & \\
\hline $\begin{array}{ll}\text { - } & \text { Web Based } \\
\text { - } & \text { Instructors Sites } \\
\text { - } & \text { BlackBoard } \\
\text { - } & \text { Mosabtec's }\end{array}$ & $\begin{array}{ll}\text { - } & \text { Text objectives } \\
\text { - } & \text { 2-3 Exams } \\
\text { - } & \text { TA assignments } \\
\text { - } & \text { Attendance }\end{array}$ & $\begin{array}{l}\text { Self-Learning } \\
\text { Content-Based }\end{array}$ & & 4 \\
\hline
\end{tabular}

Students Performance Update

Table 2 shows accounting students' performance at all levels (100 to 400) throughout the academic years 2012/13 to 2017/18. In comparison with CBA students, accounting students scored the lowest in nearly all levels. As per KU records, accounting students scored the lowest GPA in early courses for the last five years. Accounting students cumulative (aggregated) GPA at all levels has not exceeded 3.0 which is a very unfavourable indicator. Throughout the first two years, accounting students scored low GPA 1.52 and 1.79 and slightly improved during the third and fourth years 2.1 and 2.63 respectively. As per KU regulations, students must earn at least $2.0 \mathrm{GPA}$ to be eligible for graduation, while accounting students must maintain a major GPA of not less than 2.67. Otherwise, students must take extra units (over 120 units required for completing the program) once their GPA or MGPA is less than the minimum acceptable for graduation. Only when accounting students complete the 300 level courses, they start to fulfil the GPA and MGPA requirements for graduation. While still, a noticeable percentage $(7.43 \%)$ of them completed their required 120 credit units in more than four years, yet still did not achieve the minimum GPA and MGPA to graduate. Maybe one reason for this is that those students pay no tuition since KU is totally free of charge institution. Thus students have no pressure or otherwise an incentive factor to finish in 4 years. This is somewhat understandable in the first and second semester in college, but to continue till the third and fourth semesters is far from being customary.

Table 2. Accounting students performance (2012 to 2018)

\begin{tabular}{|c|c|c|c|c|c|c|c|c|c|c|c|c|}
\hline & \multicolumn{12}{|c|}{ Course Level } \\
\hline Academic Year & \multicolumn{3}{|l|}{100} & \multicolumn{3}{|l|}{200} & \multicolumn{3}{|l|}{300} & \multicolumn{3}{|l|}{400} \\
\hline 2012/13 & $\mathrm{h}$ & 1 & $\mathrm{~m}$ & $\mathrm{~h}$ & $\mathrm{~L}$ & $\mathrm{~m}$ & $\mathrm{H}$ & 1 & $\mathrm{~m}$ & $\mathrm{H}$ & 1 & $\mathrm{~m}$ \\
\hline Spring & 3.00 & 0.28 & 1.44 & 2.65 & 0.61 & 1.98 & 3.06 & 1.72 & 2.31 & 3.04 & 0.00 & 2.10 \\
\hline \multicolumn{13}{|l|}{ 2013/14 } \\
\hline Fall & 2.01 & 0.00 & 1.41 & 3.30 & 1.00 & 2.00 & 2.92 & 1.71 & 2.31 & 3.74 & 1.25 & 2.32 \\
\hline Spring & 3.70 & 0.74 & 1.75 & 3.00 & 0.00 & 1.91 & 2.69 & 1.43 & 2.25 & 3.46 & 1.57 & 2.38 \\
\hline \multicolumn{13}{|l|}{$2014 / 15$} \\
\hline Fall & 2.67 & 1.09 & 1.88 & 3.02 & 1.12 & 2.07 & 2.92 & 1.80 & 2.36 & 2.87 & 1.56 & 2.22 \\
\hline Spring & 4.00 & 0.60 & 1.82 & 2.48 & 0.33 & 1.71 & 2.82 & 1.68 & 2.34 & 3.36 & 1.21 & 2.32 \\
\hline \multicolumn{13}{|l|}{ 2015/16 } \\
\hline Fall & 4.00 & 0.47 & 1.63 & 3.70 & 0.00 & 2.01 & 2.76 & 1.54 & 2.40 & 3.75 & 1.32 & 2.35 \\
\hline Spring & 1.94 & 0.25 & 1.46 & 2.67 & 0.00 & 1.93 & 2.89 & 1.47 & 2.25 & 3.54 & 1.26 & 2.36 \\
\hline \multicolumn{13}{|l|}{ 2016/17 } \\
\hline Fall & 2.76 & 1.04 & 1.64 & 2.92 & 0.78 & 2.07 & 2.86 & 1.48 & 2.32 & 2.89 & 1.33 & 2.19 \\
\hline Spring & 2.19 & 0.00 & 1.48 & 2.73 & 1.33 & 1.99 & 2.75 & 1.13 & 2.12 & 3.91 & 1.65 & 2.53 \\
\hline \multicolumn{13}{|l|}{ 2017/18 } \\
\hline Fall & 2.83 & 1.12 & 1.26 & 3.01 & 0.93 & 1.62 & 2.79 & 1.36 & 1.03 & 2.76 & 1.27 & 1.09 \\
\hline Cumulative Average & 1.52 & & & 1.79 & & & 2.1 & & & 2.63 & & \\
\hline
\end{tabular}

Average GPA: h- Highl-Lowm-Median

Source: Kuwait University Registration Department, April 2018. 


\section{Earlier Studies}

Generally, most of the previous studies have separately investigated the effect of two factors on accounting student performance: (a) various active learning variables or techniques and (b) the use of modern educational technologies. These studies have rarely examined the effect of a combination of these two factors when used simultaneously on student's competencies. Thus, reported conclusions were founded on the application of active learning variables or techniques within parts of accounting courses rather than adopting a comprehensive competency development plan.

Although no previous research specifically addresses the impact of compressed or blocked-off variables on student learning of accountancy was found, the literature contains several studies assessing student performance in specific accounting courses, depending on the measurement of specific parameters. Some of these studies focused on the determinants of student performance in accounting courses, while others investigated the impact of large section size versus small section size on student performance. Other studies conducted focused on cognitive and personality characteristics of students. These studies offer implications on how students learn and how instructors should style their teaching.

Literature is full of research revealing the importance of accounting technical and personal skills in addition to other generic skills that are most essential for accounting graduates to retain (Stanciu and Bran; 2015). These types of studies usually improve the understanding of sustainability in higher education as many world-wide cases have supported (Ferrerro et al., 2018). Professionalism is considered a core competency in other fields of practice (Malakoff et al., 2014). There are intrinsic values attracting students to study accounting, among which gaining professional skills, involving in more field studies, being part real-world business cases, and prominently resolving real data (Pratama; 2017).

Attaining such proficient learning will also enhance the college status on maintaining accreditation throughout its lengthy process of self-evaluation then adopting corrective measures as opt. It should lead to ensuring that educational programs are delivering the perfect competencies suitable for the accounting profession. This is an obvious result as there is a direct link between accreditation and competency which materialise in the design and setting of curricula (Redelsheimer et al., 2015). Student's ability and attitude to work jointly is also an essential factor in shaping their competencies especially their personality and leadership skills (Espey, 2010). These findings are also replicated within interprofessional collaborative competency studies (Schmitz et al., 2017). It certainly improves students' performance and assists faculty in focusing on areas requiring more emphasis and collectively solving obstacles related to academia.

Accounting educators must ascertain student competency in using accounting information systems even among non-business-oriented institutions (Ambarriani, 2012). Others found that students in general lack field of exposure to the market which is extremely vital for their competency to qualify for market jobs (Rufino, 2016). Similar findings have been reached in European countries (Kaupelyte, and Legenzova; 2014). Other studies have focused on the conformity of accounting education to the market and the significant highlighting disparity between the two (Paul \& Nicoleta; 2011).

Several factors including attributes of students have been identified as closely related to subsequent academic performance. Studies in general education indicated that academic performance is significantly correlated with professional and educational learning outcomes which must be reflected within the accounting program (IAESB, 2015). Thus, individual students' competencies must be structured within the accounting program to secure a competent outcome that fulfils professional requirements. Research has also shown that among the many competencies sought are technical skills, functional capabilities, and personal talents. Overall academic performance is determined by complex interactions of several predictor variables including instructional tools and accredited contents (Marc et al., 2015). Whereas, many studies have and still emphasise the significant factor of learning assurance and the quality of accounting education (Alfaki, 2014; De Lange and Suwardy, 2012; IFAC, 2015).

For the last 50 years, calls have been addressing the need to introduce changes in accounting education to excel students' competencies. The 1989 Big Eight white paper, "Perspectives on Education: Capabilities for Success in the Accounting Profession," examined concerns about accounting graduates. In 1994, the Institute of Management Accountants (IMA) presented the results of its study addressing the needs of corporate accountants, "What Corporate America Wants in Entry-Level Accountants." The AICPA issued its "CPA Vision: Focus on the Horizon" in 1998 (Foster and Cynthia, 2007). The Accounting Education Change Commission (AECC) was created by the AAA in 1989 to develop a "change of focus in the philosophy of accounting education." The AECC concluded that accounting education was not keeping pace with the profession. Consequently, accounting education and research began a slow transformation. 
All in all, predicting the performance of students pursuing a collegiate accounting degree has received considerable attention in recent years by accounting educators and researchers. Various studies, mainly conducted in developed countries, have examined several factors associated with the success or failure of students majoring in accounting. Research results suggest that knowledge of these factors could assist in making admission and retention decisions, designing accounting curriculum, improving students' counselling, and reducing the drop or failure rate among prospective accounting students. However, factors associated with performance in an educational institution in a given environment may vary regarding variables, significance, and content once compared with another different environment. Accordingly, different educational models are placed in a country that would not match with similar models in another country, as well as from one educational institution to another.

\section{Methodology}

In 2009, the researchers conducted an initial competency measure through a capstone exam held by CBA as a partial process required for accreditation maintenance at that time. A brief questionnaire related to accounting knowledge was distributed to students sitting for that exam. Obtained results have already been elaborated in table 1 above. This study is a further version of the previous study depending on questionnaires and advanced statistical testing of parameters presumed to have an impact on student's competency. Results are hoped to assist in explaining data obtained from the registrar office at $\mathrm{KU}$ as shown in table 2 above.

It happened that this study is also coinciding with the periodical exit exam organised by CBA in spring semester 2018/2019 as a partial assurance of learning inspection in its third accreditation maintenance process. The objective is to solicit students completing this exit exam asking them about factors influencing their GPA, MGPA, and professional skills. This survey along-side with results obtained from the exit exam would somehow reflect accounting students' competencies to ensure their sufficiency for accounting era after graduating. Registered students in the researchers' classes, as well as other fellow accounting faculty classes, were also requested to participate in this query. Appendix one contains a copy of the distributed questionnaire.

\subsection{The Sample}

A historical database was obtained from KU registrar office covering the period from 2012 till 2018 academic years. Some students forming the targeted sample for the study were 332 students, which represents nearly $98 \%$ of students' population graduating from KU with accounting major during the 2017-2018 academic year (fall, spring, and summer graduation). It also represents the average number of students usually graduating from the accounting department at CBA (usually average accounting graduates of CBA are within 340). Usually, graduates from accounting program for a full academic year represent over $26 \%$ of the total graduating students from CBA, and around $4 \%$ of $\mathrm{KU}$ graduates, plus or minus.

Graduates from the accounting program during the 2017-2018 year were chosen to be the subject of this study to reflect as closely as possible the most recent and available graduation data. Also, most of those graduates were admitted into the accounting program before or in the year 2013-2014 and had to study the updated accounting curriculum which was active since 2012 following the second CBA accreditation maintenance report.

By and large, students spent significantly more time doing CBA exit exam compared with the same exam in 2009. Data showed that CBA students, in general, spent more time completing the exam than what was expected (average completion rate is 1:09 hours in comparison with 51:19 minutes in the 2009 exam).

\subsection{Variables}

Variables responsible for accounting student's performance are based on previous findings of similar research as well as on indications by CBA accounting department students who sat for the capstone exam in 2009. These variables are indicated as factors in the questionnaire sheet and are broadly familiar in business schools. These variables cover incentives and or pressure parameters for students to perform well and to be competent. Students tend to depend on internal and in no small extent on external resources to master the material. It is widely prevalent in Kuwait as well as other regional countries that students rest on external assistance in the form of private lessons to capture the material and prepare for exams. Therefore, among the seven independent variables affecting student's competency, two were presumed to be influential; namely students' personal and technical abilities, as well as their reliance on external assistance.

\subsection{The Model}

The study is aiming to measure CBA accounting students' performance which among other indicators, GPA and MGPA is used to reflect their merit in accounting knowledge. Measurement of student's competencies must be 
echoed in their academic performance regarding GPA and MGPA, although critics may be raised concerning the viability of depending solely on these two measures. The model, hence, has been structured in a way reflecting a large extent these measures in addition to other parameters that could affect students' academic performance and subsequently their competencies. Among other factors that influence student's competencies and ought to be entrenched within this model are assignments both in and out of classes, the use of extra resources, and other social as well as financial factors. Accordingly, the model is driven as follows;

$$
\mathrm{SC}=\mathrm{f}(\mathrm{GPA}+\mathrm{MGPA}+\mathrm{ICA}+\mathrm{EA}+\mathrm{XCA}+\mathrm{PFT}+\mathrm{OF})
$$

Whereas

$\mathrm{SC}=$ Students Competency (the dependent variable)

While the independent Variables are as follow:

GPA= Grade Point Average;

MGPA= Major Grade Point Average;

ICA= In-Class Assignments;

$\mathrm{EA}=$ External Assistance;

$\mathrm{XCA}=$ Extra Curriculum Assignments;

PFT= Personal, Functional, and Technical abilities;

$\mathrm{OF}=$ Other Financial and Social Factors.

Consequently, students' overall competency is hypothesized to be a function of; (1) Cumulative GPA, (2) Cumulative MGPA, (3) Classroom assignments and activities, (4) External assistance, (5) Extra curriculum assignments, (6) Personal, Functional, and technical abilities of students, (7) Other financial and social factors. Correlation among these variables would indicate active SC.

The classical methodology employed in such study is usually a survey of responses through questionnaires then conducting statistical analysis looking for possible correlations. Recommendations based on the statistical testing would provide guidelines on proper applicable remedies. Moreover, analysis of real data of accounting students' performance drawn from KU registrar office would enhance the statistical results and add value to interpretations of the correlation.

Learning characteristics of students and the different teaching tools would also assist in understanding how students build their competency. However, this is out of the scope of the present study in addition to the fact that class time and the scheduled weekly subjects limit attempts to explore these styles.

\section{Statistical Analysis}

In addition to descriptive statistics of the 332 responses, correlation analysis is used to measure the degree of association of each independent variable with students' overall competency. Since correlation analysis ignores the joint contribution of independent variables, stepwise multiple regression analysis is used to analyse the relationships between students' competency and independent variables. The linear regression model is used because simple plots of the data provide no evidence on the existence of non-linear relationships. Correlation and multiple regression analysis are also conducted separately on sub-samples for further verification.

\subsection{Descriptive Discussion}

Across the board, students scored low on capturing accounting knowledge in its primary and advanced levels as shown in table 1 above. It also shows that students lean heavily on in- class materials and do less reading in advance. The learning techniques used and practices by students are well classical as it depends primarily on lecturer delivering the materials.

An alternative analysis was performed on real data obtained from KU registrar office on accounting students completing their four years program during 2012-2018- table 2 above. Descriptive results revealed that in all four accounting levels (100 to 400 courses) students performed rather low in comparison to other CBA students. Even though their average GPA has shown some improvements in the third and fourth levels, but still these averages are beyond other CBA students. Accounting students completing their second year are hardly competent regarding cumulative GPA (1.79). Kuwait University requires students to fulfil a minimum GPA of not less than 2.67 to be eligible for transfer to accounting, and 2.0 minimum GPA for graduation. 


\subsection{Correlation Analysis}

Table 3 presents the results of Pearson Product-Moment correlation coefficients of each independent variable with GPA earned upon graduation for the full sample, as well as for each of the four individual sub-samples representing course levels. The correlations presented in Table 3 points out several observations. First, study hours exhibited the highest correlation with the dependent variable SC (4.77) followed by GPA (3.88), and then by MGPA (3.69). Correlation coefficients between SC and these three variables were $.619, .777$, and .895 respectively for all students' sample - Table 4. Second, all independent variables positively correlated with the dependent variable almost in all 4 academic years. Overall GPA had positive correlations with SC (ranging from .684 to .736) and all coefficients are significant at the .001 level.

Table 3. Descriptive statistics (continuous variables)

\begin{tabular}{llllll}
\hline Variable & $\begin{array}{l}\text { Full sample } \\
\text { Mean } \\
\text { (std.dev.) }\end{array}$ & $\begin{array}{l}\text { 1st Year } \\
\text { Mean } \\
\text { (std.dev.) }\end{array}$ & $\begin{array}{l}\text { 2nd Year } \\
\text { Mean } \\
\text { (std.dev.) }\end{array}$ & $\begin{array}{l}\text { 3rd Year } \\
\text { Mean } \\
\text { (std.dev.) }\end{array}$ & $\begin{array}{l}\text { 4th Year } \\
\text { Mean } \\
\text { (std.dev.) }\end{array}$ \\
\hline Male & 19.40 & 19.23 & 19.74 & 19.35 & 19.46 \\
\hline & $(3.10)$ & $(2.93)$ & $(3.42)$ & $(2.84)$ & $(3.39)$ \\
\hline Female* & 73,91 & 71.69 & 78.35 & 71.94 & 76.18 \\
\hline GPA & $(11.41)$ & $(0.89)$ & $(11.21)$ & $(13.21)$ & $(8.42)$ \\
\hline MGPA & 3.88 & 3.61 & 3.44 & 4.00 & 3.75 \\
\hline & $(1.25)$ & $(1.10)$ & $(1.37)$ & $(1.33)$ & $(1.16)$ \\
\hline Study Hours & 3.69 & 3.42 & 3.23 & 3.82 & 3.54 \\
\hline & $(1.46)$ & $(1.30)$ & $(1.62)$ & $(1.54)$ & $(1.37)$ \\
\hline
\end{tabular}

CBA Female students are almost 3 times male students.

Table 4. Pearson product-moment correlation coefficients of independent variables with SC

\begin{tabular}{llllll}
\hline Variable & Full Sample & 1st Year & 2nd Year & 3rd Year & 4th Year \\
\hline Male & -.105 & -.147 & -.107 & .038 & $-.289^{*}$ \\
\hline Female & $-.327^{* *}$ & -.298 & -.287 & $-.436^{* *}$ & -.124 \\
\hline GPA & $.777^{* *}$ & $.684^{* *}$ & $.854^{* *}$ & $.799^{* *}$ & $.736^{* *}$ \\
\hline MGPA & $.895^{* *}$ & $.837^{* *}$ & $.942^{* *}$ & $.875^{* *}$ & $.924^{* *}$ \\
\hline Study Hours & $.619^{* *}$ & $.374^{* *}$ & $.641^{* *}$ & $.504^{* *}$ & $.465^{* *}$ \\
\hline
\end{tabular}

* Significant at the .01 level; ** Significant at the .001 level

The independent demographic variables (Gender) had negative correlations with SC which indicate that female students performed better than male students. However, gender had rather low correlation coefficients, which is not significant at the .01 level. Third, the correlations between SC and scores in $2^{\text {nd }}$ year are the highest among all other years regarding GPA (.854) MGPA (.942), and study hours (.641). Fourth, the coefficient on MGPA is positive and significant at the .001 level and the highest in correlation (.895) among the other two independent variables GPA (.777) and study hours (.619).

\subsection{Regression Results}

Using stepwise regression process in the Statistical Package for Social Sciences (Windows SPSS), a series of different models were developed. In the model I, the dependent variable was students' competency upon graduation (SC), and data on four independent variables were employed (GPA, MGPA, ICA, and PFT). Table 5 presents the 
results of the stepwise regression analysis for the full sample and presents comparable results for the model I derived separately from the four sub-samples. It reports the beta coefficient, the F ratio, as well as the R2 change for each independent variable entered the regression equation. The $\mathrm{F}$ ratio indicates the relative contribution of each independent variable in explaining the dependent variable as the last variable entered in the regression model. This $\mathrm{F}$ ratio and its significance level (given in parenthesis) help in assessing the importance of a single variable in explaining the variation in the dependent variable. The R2 and the Adjusted R2 for the model are reported at the end of each table. Their values show that the model is significant at the .001 level. Thus, the model provided a good fit for the SC variable.

Table 5. Summary of regression analysis - full sample

The model I- Dependent variable: SC

\begin{tabular}{llll}
\hline Independent Variable Entering the Equation & Beta Coeff. & F Ratio (Prob.) & R2 Change \\
\hline GPA & .599 & $\begin{array}{l}236.99 \\
(.000)\end{array}$ & .800 \\
\hline MGPA & .030 & $\begin{array}{l}50.69 \\
(.000)\end{array}$ & .043 \\
\hline ICA & .067 & $\begin{array}{l}11.88 \\
(.001)\end{array}$ & .013 \\
\hline PFT & & 9.32 & .008 \\
\hline
\end{tabular}

$\mathrm{F}=261.17 ; \mathrm{R}^{2}=.864 ;$ Adjusted $\mathrm{R}^{2}=.861$

All beta coefficients signs of the independent variables entered the regression were positive ranging from .030 to .599. GPA is undoubtedly the most contributing predictor variable to overall students' performance in accounting program. GPA was consistently having the largest marginal contribution in explaining performance across all sub-samples as well as for the full sample and was highly statistically significant. This reinforces the initial conclusion revealed from correlation analysis reported earlier (Table 3). PFT followed GPA slightly in this sense which is tolerable as it depends on students' ability to score high and perform well in terms of GPA, particularly in early years where most courses taken by students are general and of non-business at large. Thus, GPA is not yet premeditated as students have taken 2 or 3 accounting courses whereas MGPA requires twice this number of courses to be considered as indicator factor.

Likewise, ICA contributed to explaining variation in students' performance and linked to personal and technical abilities of students (PFT). Although, we had almost identical Beta Coeff $(0.067 \& 0.068)$ for both variables, it showed little usefulness as explanatory variables when used jointly with other variables.

\subsection{Gender Criterion}

Students' gender factor was tested for possible influence using the same independent variables shown in table 5. The purpose is to validate any possible differences in performance among male versus female students concerning those variables. The stepwise regression results of this test (Table 6) demonstrate the dedication of female students in terms of the independent variables' effect on their competency. This is, normal in all CBA departments since female students are more abundant in number and spend more study hours off class. Almost in all patterns, they scored higher than male students. 
Table 6. Summary of regression analysis-sample split according to sex

Model 1- Dependent variable: SC

\begin{tabular}{lllllll}
\hline Independent Variable & \multicolumn{3}{l}{ Male Students } & \multicolumn{4}{l}{ Female Students } \\
\cline { 2 - 7 } Entering the Equation & $\begin{array}{l}\text { Beta } \\
\text { Coef. }\end{array}$ & $\begin{array}{l}\text { F Ratio } \\
(\text { Prob. })\end{array}$ & $\begin{array}{l}\text { R2 } \\
\text { Change }\end{array}$ & $\begin{array}{l}\text { Beta } \\
\text { Coef. }\end{array}$ & $\begin{array}{l}\text { F Ratio } \\
\text { (Prob.) }\end{array}$ & $\begin{array}{l}\text { R2 } \\
\text { Change }\end{array}$ \\
\hline GPA & .586 & $\begin{array}{l}249.41 \\
(.000)\end{array}$ & .700 & .634 & $\begin{array}{l}456.34 \\
(.000)\end{array}$ & .887 \\
\hline MGPA & .024 & $\begin{array}{l}17.87 \\
(.000)\end{array}$ & .043 & .032 & $\begin{array}{l}30.85 \\
(.000)\end{array}$ & .048 \\
\hline EX & .078 & $\begin{array}{l}11.22 \\
(.001)\end{array}$ & .025 & .083 & $\begin{array}{l}12.40 \\
(.001)\end{array}$ & .037 \\
\hline PFT & .060 & $\begin{array}{l}4.97 \\
(.028)\end{array}$ & .011 & .052 & $\begin{array}{l}.02 \\
(.041)\end{array}$ & .023 \\
\hline OF & .048 & $\begin{array}{l}3.96 \\
(.018)\end{array}$ & .003 & .064 & $\begin{array}{l}.045 \\
(.023)\end{array}$ & .006 \\
\hline
\end{tabular}

$\mathrm{F}=91.37 ; \mathrm{F}=212.96 ; \mathrm{R} 2=.779 ; \mathrm{R} 2=.939 ;$ Adjusted $\mathrm{R} 2=.770 ;$ Adjusted $\mathrm{R} 2=.935$

\subsection{Assignments Criterion}

Similarly, the assignments criterion both in and out of class associated with five independents variables and thus students' performance was tested. Table 7 presents the results of the stepwise regression analysis for the sample split and present similar results for the model I derived separately from the five sub-samples. It reports the beta coefficient, the F ratio, as well as the R2 change for each independent variable entered the regression equation as correlated to ICA and XCA. Results again support previous readings that GPA and to a lesser extent PFT, as well as EA, have impact Act on assignment variables and subsequently student's competency. Essentially, GPA is enhanced by students' assignments is understandable, yet the noticeable remark is the negative two-side impact among EA and extra curriculum assignments. It is strange to see such results as students tend to depend on external assistance in completing assignments especially those requiring in-depth analysis and some judgment.

Table 7. Summary of regression analysis sample split according to in class \& extra curriculum assignments

The model I - Dependent variable: SC

\begin{tabular}{|c|c|c|c|c|c|c|}
\hline \multirow{3}{*}{$\begin{array}{l}\text { Independent Variable } \\
\text { Entering the Equation }\end{array}$} & \multicolumn{3}{|c|}{ In Class } & \multicolumn{3}{|c|}{ Extra Curriculum Assignments } \\
\hline & Beta & F Ratio & R2 & Beta & F Ratio & R2 \\
\hline & Coef & (Prob.) & Change & Coef. & (Prob.) & Change \\
\hline \multirow{2}{*}{ GPA } & .494 & 273.52 & .765 & .975 & 470.84 & .853 \\
\hline & & $(.000)$ & & & $(.000)$ & \\
\hline \multirow{2}{*}{ MGPA } & .028 & 31.91 & .065 & .025 & 11.60 & .019 \\
\hline & & $(.000)$ & & & $(.001)$ & \\
\hline \multirow{2}{*}{ EA } & .071 & 6.97 & .012 & - & - & - \\
\hline & & $(.010)$ & & & & \\
\hline \multirow{2}{*}{ PFT } & .074 & 4.79 & .008 & - & - & - \\
\hline & & $(.032)$ & & & & \\
\hline \multirow{2}{*}{ OFT } & - & - & - & -.139 & 6.74 & .010 \\
\hline & & & & & $(.011)$ & \\
\hline
\end{tabular}

$\mathrm{F}=110.08 ; \mathrm{F}=196.59 ; \mathrm{R} 2=.874 ; \mathrm{R} 2=.882 ;$ Adjusted $\mathrm{R} 2=.865 ;$ Adjusted $\mathrm{R} 2=.877$ 


\section{Model II}

Repeating the coefficient test for any correlation among the five independents variables and their impact on student's competency is the notion of model II. Results of this test (table 8) pointed out that Model II provided some consistency among these variables especially GPA which had the highest full sample readings among the five variables. In second place came PFT variable as F ratio for the model was statistically significant at the .001 level. Both Models I and II identified GPA, MGPA, and PFT as significant factors in explaining performance whether in terms of overall GPA in all courses upon graduation (GPA) or major GPA in accounting courses only (MGPA). GPA at the end of the second year achieved consistent results in both models as it had the largest $\mathrm{F}$ ratio and R2 change. However, the order of the other variables entered the regression equations (MGPA, EA, and PFT), and thus their relative importance in explaining performance when used jointly with other predictors where somewhat different in the two models.

Table 8. Summary of regression analysis - full sample

Model II - Dependent variable: SC

\begin{tabular}{llll}
\hline $\begin{array}{l}\text { Independent Variable } \\
\text { Enteric the Equation }\end{array}$ & $\begin{array}{l}\text { Beta } \\
\text { Coeff }\end{array}$ & $\begin{array}{l}\text { F Ratio } \\
\text { (Prob.) }\end{array}$ & $\begin{array}{l}\text { R2 } \\
\text { Chance }\end{array}$ \\
\hline \multirow{2}{*}{ GPA } & .432 & $\begin{array}{l}58.02 \\
(.000)\end{array}$ & .668 \\
& & 20.93 & .063 \\
MGPA & .137 & $(.000)$ & \\
\hline \multirow{2}{*}{ EA } & & 21.494 & .036 \\
& .129 & $(.000)$ & \\
\hline \multirow{2}{*}{ PFT } & & 20.93 & .020 \\
\hline \multirow{2}{*}{ OFT } & .146 & $(.000)$ & \\
& & 17.17 & .020 \\
\hline
\end{tabular}

$\mathrm{F}=136.25 ; \mathrm{R} 2=.807 ;$ Adjusted $\mathrm{R} 2=.801$

Also, results of Model II indicate that there is additional usefulness in including PFT as a predictor of performance measured by MGPA. As anticipated, more weights will be given to the performance in individual accounting courses if overall success in accounting program is being judged based on MGPA. This explains the relatively higher weight of the three individual accounting courses Acc111, Acc112, and Acc201 over other advanced courses of 300 or 400 level. This conclusion reinforces the observation found from the rather high correlation coefficient between MGPA and individual accounting courses (Correlation coefficients between MGPA and Acc111, Acc112, and Acc201 were $.5315, .6705$. and .6430 respectively - table 9).

Table 9. Summary of correlation coefficient analysis - sample split

Model III - Dependent variable MGPA

\begin{tabular}{lll}
\hline $\begin{array}{l}\text { Independent Variable } \\
\text { Enteric the Equation }\end{array}$ & $\begin{array}{l}\text { Beta } \\
\text { Coeff. }\end{array}$ & $\begin{array}{l}\text { Correlated } \\
\text { Coeff. }\end{array}$ \\
\hline Acc111 & .296 & .5315 \\
\hline Acc112 & .221 & .6705 \\
\hline Acc201 & .205 & .6430 \\
\hline Acc342 & .163 & .3892 \\
\hline Acc444 & .097 & .3352 \\
\hline
\end{tabular}




\subsection{Multicollinearity}

Multicollinearity refers to the condition of a high degree of interdependence among the independent variables which causes difficulties in assessing the individual effect of an independent variable upon the dependent variable. Table 10 presents the results of simple pairwise correlation analysis for the various independent variables. The results show few cases of moderate intercorrelations that exist among some independent variables, particularly among MGPA, ICA, PFT, and OF. To investigate the existence of multicollinearity in the regression model, tolerance criterion has been applied which requires that the tolerance of each variable in the model (a measure of the proportion of variability not explained by the other variables) should be high enough to be acceptable. Tolerance of independent variables in the regression equation for Model I and Model II was between .4 and .75. Based on these results it was judged that multicollinearity does not appear to be a severe problem in the model.

Table 10. Simple correlation coefficients between independent variables multicollinearity test

\begin{tabular}{llllllll}
\hline & GPA & $\begin{array}{l}\text { MGPAM } \\
\text { GPA }\end{array}$ & ICA & EA & XCA & PFT & OF \\
\hline GPA & 1 & -.05 & .30 & .05 & -.26 & -.08 & -.04 \\
\hline MGPA & 1 & -.15 & -.26 & -.22 & -.34 & -.38 \\
\hline ICA & & 1 & -.15 & -.07 & -.37 & -.14 & -.19 \\
\hline EA & & 1 & -.07 & .14 & .16 \\
\hline XCA & & & 1 & .48 & .49 \\
\hline PFT & & & & 1 & .87 \\
\hline OF & & & & & 1 \\
\hline
\end{tabular}

Given relatively moderate intercorrelations among the abovementioned independent variables and as a remedy, an alternative regression model was developed (Model IV) in which two collinear variables (PFT and OF) were dropped from the regression in Model II. Table 11 reports the results of stepwise regression for Model IV for the full sample. All regressions were found to be statistically significant at the .001 level.

The results presented in Table 11 indicate that dropping ICA and XCA did not change the previous conclusion of Model I regarding the importance of GPA in predicting students' overall performance. GPA by far provided the most important variable in explaining success in the accounting program; a conclusion that is consistent throughout the various regression models developed in this study. When comparing results of Model II (Table 8) with analogous results of Model I (Tables 3,4, and 5), it appears that the relative contribution of ICA to explaining performance comes next to GPA in the two models. Also, the effect of dropping the two independent variables (ICA and XCA) allowed MGPA to enter the regression equation for the full sample as well as for the two sub-samples representing Kuwaiti accounting students. Grades in the first introductory accounting courses again showed a significant explanatory power in predicting the performance of accounting students. Since it is more desirable to identify candidates for admission to accounting program at an earlier point in their academic study, Model II provides an advantage over Model I in identifying factors related to overall performance. The omission of ICA and XCA in Model II resulted in a reduction in the overall R2 of the full sample by only .014 when compared with that of Model I (.864 - .850). Therefore, results of Model II suggest that accounting students' grades in pure accounting courses (i.e. Accounting Principles I \& II) could be regarded as a substitute for the more analysis on GPA and students' performance especially in the first two years of their enrolment, thus permitting an earlier prediction of students' performance.

Table 11. Summary of stepwise regression analysis

Model IV - Dependent variable sc- full sample

\begin{tabular}{lll}
\hline Independent variable & F Ratio P Ratio & R2 \\
Entering the Equation & (Prob.). & Chance \\
\hline
\end{tabular}




\begin{tabular}{lll}
\hline GPA & 676.95 & .800 \\
& $(.000)$ & \\
\hline MGPA & 45.49 & .043 \\
& $(.000)$ & \\
\hline EA & 7.65 & .007 \\
& $(.020)$ &
\end{tabular}

$\mathrm{F}=315.1 \overline{1 ; \mathrm{R} 2=0.850 ; \text { Adjusted } \mathrm{R} \sim=0.847}$

\section{Conclusions}

Results of this study provide evidence that GPA earned by accounting students at CBA is the most important variable associated with their overall performance upon graduation. Other variables such as MGPA, external assistance (EA), in-class assignments (ICA), students' personal and technical abilities (PFT), and other financial and social factors (FT) have lesser degree of significance on their performance. Results also indicate that independent variables examined in the study provided a significant contribution in predicting performance when used jointly with other variables. Also, it was revealed that grades in later academic years are better associated with performance than grades in the first year, and significantly contribute to students' competency when used instead of the more advanced accounting courses.

For an Arabic speaking university, the principal factor behind instable accounting education outcome would either be related to student poor English or their educational foundation at public high schools. Generally, students at the secondary and high schools were taught through the "spoon feeding" approach rather than the self-learning approach, which is quite catastrophic once they reach higher education at the university level. Finally, these findings imply that better use of available resources at Kuwait University may be achieved by considering higher GPA and MGPA as factors in admitting students into accounting program after completing their founding year at CBA.

Comparably, most of the previous studies have separately investigated the effect of two factors on accounting student performance: (a) various active learning variables or techniques and (b) the use of modern educational technologies. Thus, this study has added value in terms of examining the effect of a combination of these two factors simultaneously. Our conclusions were related to adopting active learning techniques within accounting courses rather than adopting a comprehensive competency development plan. In this respect, these conclusions are to some extent comparable to previous studies (Stanciu and Bran; 2015; Ferrerro et al., 2018; Malakoff et al., 2014). Also, it was revealed that students attend accounting courses for the intrinsic values attracting them to accounting such as gaining professional skills and prominently resolving real data which in turn point out to their competency. This is to a large extent analogous to earlier studies (Pratama; 2017; Redelsheimer et al., 2015; Espey, 2010; Schmitz et al., 2017). It certainly improves students' performance and assists faculty in focusing on areas requiring more emphasis and educators must ascertain student competency in using accounting information systems even among non-business-oriented institutions, equivalent to what was revealed in preceding studies (Ambarriani, 2012; Rufino, 2016; Kaupelyte, and Legenzova; 2014; Paul \& Nicoleta; 2011).

Future studies may include testing for other non-parametric variables affecting accounting students' performance such as the influence of competitive behaviour among junior students, the growing pressure by the accounting profession to promote accounting graduates and the effect of the enrolment of students in disrespect to their preferences at KU. In overall, more emphasis should be given to the improvement of student's competencies through the involvement of both the private and public sector in the instrumental tools and content of CBA accounting program.

\section{References}

Alfaki, A. A. (2014). A proposal for the adoption of Accounting Educational Standards and its role in Strengthening Accounting Curriculums in Saudi. Economics and Management Journal, 7(16).

Alrashed, W. (2001). Determinates of Accounting Students' Performance in Kuwait University. Journal of King Abdulaziz University: Economics and Administration, 15(2), 3-17. https://doi.org/10.4197/Eco.15-2.1 
Ambarriani, A. (2012). The MGPA Act of Manager's Knowledge Towards Manager's Style in Using Management Accounting Information and Activity-Based Management (Study in Hospitals in Yogyakarta and Central Java). Review of Integrative Business and Economics Research, 1(1), 356-373.

De Lange., P., Jackling, B., \& Suwardy, T. (2012, July 1-30). Continuing Professional Development in the Accounting Profession: Evidence from the Asia Pacific Region. In Potter B. \& Birt, J. (Eds.), Proceedings of Accounting and Finance Association of Australia and New Zealand Conference. Carlton. Australia.

Espey, M. (2010). Valuing Teams: What Influences Student Attitudes?. NACTA Journal, 54(1), 31-40.

Ferrero-Ferrero, I., Fernandez-Izquierdo, M.-A., Tores, M. J., \& Belles-Colomer, L. (2018). Stakeholder Engagement in Sustainability Reporting in Higher Education: An Analysis of Key Internal Stakeholders' Expectations. International Journal of Sustainability in Higher Education, 19(2), 313-336.

Foster, S., \& Cynthia, B.-L. (2007). The core Competency Framework: A new element in the accounting Call for Accounting Education Change in the United States. Accounting Education Journal, 12(1), 33-47.

IAESB. (2015). Proposed Drafting Changes to International Education Standards: Framework for International Education Standards for Professional Accountants and Aspiring Accountants. Retrieved from www.ifac.org

IFAC. (2015). Competencies Requirements for Audit Professionals: A19-A31. Education Committee. Retrieved from www.ifac.org/system/files/publications/files/IAESB

Kaupelyte, D., \& Legonzova, R. (2014). Do Lithuanian Higher Education Accounting Programs Reflect Accounting Harmonization in the EU?. CBU International Conference Proceedings (Vol. 2).

Malakoff, G. L., Payne, C. L., Staton, L. J., Kolade, V. O., \& Panda, M. (2014). Accounting for Professionalism: An Innovative Point System to Assess Resident Professionalism. Journal of Community Hospital Internal Medicine Perspectives, 4. https://doi.org/10.3402/jchimp.v4.23313

Marc, M., Burnett, R. D., Skousen, C., \& Akaaboune, O. (2015). Accounting Education and Reform: A Focus on Pedagogical Intervention and its long-term Effects. The Accounting Educators Journal, XXV, 67-93.

Marc, M., et al. (2015). Accounting Education and Reform: A Focus on Pedagogical Intervention and its long-term Effects. The Accounting Educators Journal, XXV, 67-93.

Paul, D., \& Nicoleta, C. (2011). The Conformity of the University Accounting Education Curriculum to the Needs of the Labor Market in Romania. International Journal of Arts \& Sciences. Cumberland, 4(15), 265-276.

Pratama, A. (2017). Factors Affecting Students' Learning Interest in an Accounting Study Programme: A Study in Bandung City, West Java, Indonesia. Review of Integrative Business and Economics Research, 6(2), 295-311.

Redelsheimer, C. L., Boldenow, R., \& Marshal, P. (2015). Adding Value to the Profession: The Role of Accreditation. Journal of Forestry, 113(6), 566-570. https://doi.org/10.5849/jof.15-028

Rufino, H. D. (2016). Core Competencies for Accountants of BS Accountancy Students of Tarlac State University: Input to Accounting Education. Review of Integrative Business and Economics Research, 5(4), 16-28.

Schmitz, C. C., Radosevich, D. M., Jardine, P., MacDonald, C. J., \& Trumpower, D. (2017). The Interprofessional Collaborative Competency Attainment Survey (ICCAS): A Replication Validation Study. Journal of Interprofessional Care, 31(1), 28-34. https://doi.org/10.1080/13561820.2016.1233096

Stanciu, V., \& Bran, F. P. (2015, March). The Accounting Profession in the Digital Era. Calitatea: Acces la Success, $16(\mathrm{~S} 1), 546-550$. 


\section{Appendix}

Accounting Students Competencies

Kuwait University

Dear participant,

The purpose of this short questionnaire is to explore accounting students' awareness of several issues related to their field of specialisation. This study aims to determine factors contributing to accounting students' performance at the college level and accordingly boosting their abilities and competencies. Results of this study are merely used in the context of this project and shall not be used in other devotions. All gathered data shall be analyzed and contained in secrecy and shall be made available for those interested in the study's theme after results compilation and only in generic format. The questionnaire will take 5-6 minutes to be completed. If for any reasons you prefer, these questions can be delivered as an interview format as the researcher or his assistant can assist in this process.

If further clarifications are needed, please forward all queries to the researcher.

Full appreciation for participating in this purely academic research.

Regards,

\section{Part I: Study Distinction}

This part is to explore factors affecting students' performance in general business studies. Please circle the degree of importance of each of the following:

\begin{tabular}{|c|c|c|c|c|c|}
\hline Factor Influencing GPA & $\begin{array}{l}\text { Not } \\
\text { Important }\end{array}$ & $\begin{array}{l}\text { Somewhat } \\
\text { Important }\end{array}$ & Important & $\begin{array}{l}\text { Very } \\
\text { Important }\end{array}$ & $\begin{array}{l}\text { Critically } \\
\text { Important }\end{array}$ \\
\hline 1. Hard working in \& after class & 1 & 2 & 3 & 4 & 5 \\
\hline 2. Team work in \& out class & 1 & 2 & 3 & 4 & 5 \\
\hline $\begin{array}{l}\text { 3. Good consultations on registered } \\
\text { courses }\end{array}$ & 1 & 2 & 3 & 4 & 5 \\
\hline 4. Comparability with academic discipline & 1 & 2 & 3 & 4 & 5 \\
\hline 5. Depending on Private lessons & 1 & 2 & 3 & 4 & 5 \\
\hline 6. Improved student learning tools & 1 & 2 & 3 & 4 & 5 \\
\hline 7. Attending TA's classes & 1 & 2 & 3 & 4 & 5 \\
\hline 8. $\quad$ Dense background in business & 1 & 2 & 3 & 4 & 5 \\
\hline 9. $\quad$ Frequent advices from peer students & 1 & 2 & 3 & 4 & 5 \\
\hline 10. Self-pressure & 1 & 2 & 3 & 4 & 5 \\
\hline 11. Parental \& family guidance & 1 & 2 & 3 & 4 & 5 \\
\hline 12. Funds availability & 1 & 2 & 3 & 4 & 5 \\
\hline 13. Less social activities & 1 & 2 & 3 & 4 & 5 \\
\hline 14. Desire to secure respectable job & 1 & 2 & 3 & 4 & 5 \\
\hline 15. Time management & 1 & 2 & 3 & 4 & 5 \\
\hline
\end{tabular}




\section{Section II. Accounting Competency}

For this survey, accounting competency refers to the knowledge of accounting principles, issues, and the know-how of its practices and procedures. This part is testing the factor affecting students' competency in accounting. Please rate the importance of each of the following factors to accounting education:

\begin{tabular}{|c|c|c|c|c|c|}
\hline Factors Influencing MGPA & $\begin{array}{l}\text { Not } \\
\text { Important }\end{array}$ & $\begin{array}{l}\text { Somewhat } \\
\text { Important }\end{array}$ & Important & $\begin{array}{l}\text { Very } \\
\text { Important }\end{array}$ & $\begin{array}{l}\text { Critically } \\
\text { Important }\end{array}$ \\
\hline 16. Reduced load (course release) & 1 & 2 & 3 & 4 & 5 \\
\hline $\begin{array}{l}\text { 17. Focusing on Quantitative subjects } \\
\text { in accounting }\end{array}$ & 1 & 2 & 3 & 4 & 5 \\
\hline $\begin{array}{l}\text { 18. Selecting nominated instructor by } \\
\text { counter fellow students }\end{array}$ & 1 & 2 & 3 & 4 & 5 \\
\hline 19. Group studying & 1 & 2 & 3 & 4 & 5 \\
\hline $\begin{array}{l}\text { 20. Attending Summer courses with } \\
\text { minimum loads }\end{array}$ & 1 & 2 & 3 & 4 & 5 \\
\hline $\begin{array}{l}\text { 21. Utilising textbook resources } \\
\text { provided by the publisher }\end{array}$ & 1 & 2 & 3 & 4 & 5 \\
\hline 22. Seeking colleague's assistance & 1 & 2 & 3 & 4 & 5 \\
\hline 23. Leaning on external assistance & 1 & 2 & 3 & 4 & 5 \\
\hline
\end{tabular}

Part III. Accounting Professional Skills

This part is to assess factors affecting accounting students' professional skills. Please circle as appropriate:

\begin{tabular}{|c|c|c|c|c|c|}
\hline \multirow[t]{2}{*}{ Factors influencing professional skills } & \multirow{2}{*}{$\begin{array}{l}\text { Not } \\
\text { Important }\end{array}$} & \multicolumn{2}{|l|}{ Somewhat } & \multirow{2}{*}{$\begin{array}{l}\text { Very } \\
\text { Important }\end{array}$} & \multirow{2}{*}{$\begin{array}{l}\text { Critically } \\
\text { Important }\end{array}$} \\
\hline & & Important & Important & & \\
\hline 24. Accounting Firms Training & 1 & 2 & 3 & 4 & 5 \\
\hline 25. Real world cases & 1 & 2 & 3 & 4 & 5 \\
\hline 26. Relevance Audit discipline & 1 & 2 & 3 & 4 & 5 \\
\hline $\begin{array}{l}\text { 27. Field visit to accounting departments at } \\
\text { government units }\end{array}$ & 1 & 2 & 3 & 4 & 5 \\
\hline $\begin{array}{l}\text { 28. Latest update on accounting standards } \\
\text { applications }\end{array}$ & 1 & 2 & 3 & 4 & 5 \\
\hline 29. Use of accounting software & 1 & 2 & 3 & 4 & 5 \\
\hline $\begin{array}{l}\text { 30. Technological Accounting Information } \\
\text { systems support }\end{array}$ & 1 & 2 & 3 & 4 & 5 \\
\hline $\begin{array}{l}\text { 31. Inviting professional experts \& known } \\
\text { speakers in accounting }\end{array}$ & 1 & 2 & 3 & 4 & 5 \\
\hline
\end{tabular}

Background Information

This information is requested to gain a better understanding of the population being studied. Please circle (or highlight) the appropriate response.

Gender: 1. Female 2. Male

College Year: 1. ( ) 2. ( ) 3. ( ) 4. ( )

GPA: $1.0-2.0(\quad) \quad 2.0-2.50(\quad) 2.50-3.0(\quad) \quad 3.0-3.5(\quad) \quad 3.50-4.0(\quad)$

MGPA: $1.0-2.0(\quad) \quad 2.0-2.50(\quad) \quad 2.50-3.0(\quad) \quad 3.0-3.5(\quad) \quad 3.50-4.0(\quad)$

Number of study hours per day: Less than 3( ) 3-5( ) 5-7 ( ) More than 7( )

Thanks for your cooperation 